\title{
Quo Vadis EHEA: Balancing Structural Continuation and Political Variety
}

\author{
Jens Jungblut, Peter Maassen, and Mari Elken
}

\section{Introduction}

European integration in higher education entered a new era with the signing of the Bologna Declaration in 1999 (Bologna Process 1999) and its subsequent implementation, generally referred to as the Bologna Process (Maassen and Olsen 2007). In March 2010, along with the anniversary of the Bologna Process' first decade, the European Higher Education Area (EHEA) was launched. The main overall objective of the EHEA was to ensure more comparable, compatible and coherent systems of higher education in Europe. According to the official website of the EHEA, ${ }^{1}$ the 48 participating countries with different political, cultural and academic traditions agreed to reform higher education on the basis of common key values-including academic freedom, institutional autonomy, freedom of expression, independent student unions, and free movement of students and staff. While the reforms have reduced the structural barriers for student and staff mobility, little progress has been realised when it comes to the adaptation of the common values. As will be argued in this paper, it can be concluded that in some of the EHEA countries the adherence of fundamental values, e.g. with respect to academic freedom, has deteriorated instead of improved since 2010 .

J. Jungblut

Department of Political Science, Faculty of Social Sciences, University of Oslo, Oslo, Norway

e-mail: jungblut@stv.uio.no

P. Maassen (更)

Department of Education, Faculty of Educational Sciences, University of Oslo, Oslo, Norway

e-mail: peter.maassen@iped.uio.no

M. Elken

Nordic Institute for Studies in Innovation, Research and Education (NIFU), Oslo, Norway e-mail: mari.elken@nifu.no

${ }^{1}$ See: http://www.ehea.info, accessed 10 February 2020. 
At the Ministerial Conference in Paris in 2018, the participating Ministers agreed that they want a more ambitious EHEA beyond 2020 (Bologna Process 2018). In elaborating this strategic ambition, the Ministers expressed the EHEA's commitment to extend integrated transnational cooperation in higher education, research and innovation, with the aim to increase the mobility of staff, students and researchers, and to develop more joint study programmes throughout the whole EHEA. In the period 2018-2020, the full potential of the EHEA was to be unlocked (Bologna Process 2018: 2) through a focus on:

1. The compatibility of the three-cycle system with the overarching framework of the EHEA and first and second cycle degrees scaled by ECTS.

2. The compliance of the EHEA with the Lisbon Recognition Convention;

3. The compliance of quality assurance in the EHEA countries with the Standards and Guidelines for Quality Assurance in the EHEA (ENQA 2015).

In addition, the Ministers want European higher education to play a key role in meeting the UN's Sustainable Development Goals $\left(\mathrm{SDGs}^{2}\right)$. At the same time, while the Paris Communiqué acknowledges that fundamental values, such as academic freedom and institutional autonomy (Bologna Process 2018: 1), have been challenged in recent years in some of the EHEA countries, the promotion and protection of these in the entire EHEA is left to political dialogue and cooperation. Given the already referred to deterioration of the situation in a number of EHEA countries, it can be argued that the Paris Communiqué exemplifies the symbolic nature of the commitment to basic values and principles, and the lack of effective action for truly making fundamental values and principles a key component of the EHEA.

The symbolic nature of the commitment to fundamental values in the EHEA comes at a time when the overall European integration project is going through a difficult and in many respects uncertain period. For example, the consequences of Brexit; the rise of nationalistic, anti-EU political parties and movements; important disagreements among EU member states on key ideas and principles underlying European integration, as well as the growing global political and economic rivalry, are all forming serious challenges for the further development of European collaboration and integration. In the end, these challenges might also threaten the further development of the EHEA. Consequently, key questions to address for the next phase of the EHEA are:

- What kind of universities for what kind of Europe?

- How can fundamental values and principles become a sine qua non in the next phase of the EHEA?

In this paper, we will start with a discussion of the possible relevance of science diplomacy for addressing these questions. Next, we will analyse intra-European political tensions, with a number of member states having moved away from basic European values and principles concerning liberal democracy and open societies. Further, we

\footnotetext{
${ }^{2}$ See: https://www.un.org/sustainabledevelopment/sustainable-development-goals/ (accessed 10 February 2020).
} 
will examine the impact of the European Universities Initiative ${ }^{3}$ and funding patterns of other European education programmes on the further development of the EHEA. Finally, we will discuss the consequences of growing global higher education competition. What does the 'European' in EHEA stand for in this competition, and will the EHEA represent one coherent, strong voice and position that will allow Europe to remain a global key actor in higher education?

\section{Science Diplomacy and the EHEA}

The challenges that Europe is facing globally have been clearly addressed on several occasions by its political leaders. The German Chancellor Angela Merkel, for example, raised the issue of the importance for Europe to put up a united front to be able to deal adequately with threats of global rivalry in an interview published May 2019 in six newspapers: "Europe must reposition itself to stand up to the challenges posed by its big global rivals... This is indeed a time when we need to fight for our principles and fundamental values" (Guardian, 15 May 2019). ${ }^{4}$ In this, Merkel is primarily referring to the USA, China and Russia, with challenges that range from the US monopoly over digital industries through China's economic power to Russian interference in democratic elections. In addition, also the President of the European Commission Ursula von der Leyen has addressed the importance of key values for Europe's external relations: "We must use our diplomatic and economic strength to support global stability and prosperity... and be better able to export our values and standards." 5

For securing Europe's future global political influence and economic competitiveness, the importance of developing more effective connections between science and innovation is emphasized in various national and EU policy and programme initiatives, including Horizon Europe. ${ }^{6}$ the EU's next research and innovation programme to succeed Horizon 2020 in 2021, and the European Education Area, ${ }^{7}$ Horizon Europe consists of three pillars, that is, pillar 1, 'Excellent Science', pillar 2, 'Global Challenges and European Industrial Competitiveness', and pillar 3, 'Innovative Europe'. In the third pillar, the European Innovation Council is included as a new instrument for supporting various types of innovations that are too risky for private investors. An important ambition with respect to Horizon Europe is that Europe can do better

\footnotetext{
${ }^{3}$ See: https://ec.europa.eu/education/education-in-the-eu/european-education-area/european-uni versities-initiativel_en (accessed 10 February 2020).

${ }^{4}$ See: https://www.theguardian.com/world/2019/may/15/angela-merkel-interview-europe-eu-uni te-challenge-us-russia-china (accessed 10 February 2020)

${ }^{5}$ See: https://ec.europa.eu/commission/sites/beta-political/files/mission-letter-josep-borrell-2019 Ł_en.pdf (accessed 10 February 2020).

${ }^{6}$ See: https://ec.europa.eu/info/horizon-europe-next-research-and-innovation-framework-progra mmel_en, (accessed 10 February 2020).

${ }^{7}$ See: https://ec.europa.eu/education/education-in-the-eu/european-education-area_en (accessed 10 February 2020).
} 
at transforming its excellent research into leadership in innovation and entrepreneurship. In this, an example of a fundamental value issue, as referred to by Merkel, is the choice between technologizing humanity versus humanising technology, with European politicians stating that they want to promote the latter.

Obviously, the interest of the EU and its member states in the connection between science and innovation is not confined to an isolated science policy arena. Science has become more and more integrated into other policy areas and arenas as visible, for example, in the growing link between science and foreign affairs, referred to with the term 'science diplomacy'. In a speech given in 2015 in Washington, D.C., then EU commissioner Moedas argued that "Science diplomacy is the torch that can light the way, where other kinds of politics and diplomacy have failed" (Moedas 2015). This perspective is further elaborated as follows in an article published in 2016: "Scientific cooperation has an indisputable role in effective European neighbourhood policy, international relations, and development policy. Therefore, as commissioner for research, science, and innovation, I want to see the EU play an increasingly active and visible role in international science diplomacy. This can be achieved, namely, by using the universal language of science to maintain open channels of communication in the absence of other viable foreign policy approaches" (Moedas 2016: 2). This quote reflects the strong belief that scientific interactions can have a stabilizing influence on the relationships between countries with seriously incongruent ideological approaches and political systems. From this perspective, science diplomacy can be described as " ... the use of scientific collaborations among nations to address the common problems." (Federoff 2009: 9). This implies that science diplomacy represents a path of "common interest building", opposed to "conflict resolution" (Berkman 2019: 65). For example, the SDGs clearly represent the outcomes of an effort of (global) common interest building. Consequently, science diplomacy is assumed to play a central role in the global and regional efforts to balance national needs with common interests among two or more countries (Berkman 2019: 79).

How did science diplomacy contribute to the development of the EHEA? Did science diplomacy result in a growing adherence to fundamental values and principles among the 48 participating countries within the EHEA? In addressing these questions, we will examine the political interest in the EHEA, followed by an analysis of the extent to which the EHEA countries adhere to academic freedom, being one of the most central fundamental values the participating countries have agreed upon. We will start by briefly discussing the growing variety among the EHEA countries ideological foundation of national governance models with respect to higher education.

\footnotetext{
${ }^{8}$ See: https://ec.europa.eu/research/iscp/pdf/newsletter/international-research-update_57_june2015.pdf (accessed 17 March 2020).
} 


\section{National Contexts}

For discussing the variety in the ideas underlying specific national arrangements for higher education, we will use in this paper the basic visions on higher education governance and organization identified by Olsen (2007: 28-33). These visions are recognisable in national governance models with respect to higher education in Europe (Maassen and Olsen 2007), and using them allows us to identify three groups of countries.

First, in some countries a market- and competition-oriented approach is emphasized in the government's higher education governance model. Second, there is a group of countries in which higher education is primarily regarded as one of the key instruments for implementing and realizing national political agendas. In the third group of countries, the public authorities adhere to a more balanced mixture of ideas underlying their higher education governance model overemphasizing one dominant vision. How are higher education institutions affected by the dominant governance vision in their national context? First, in those countries that most directly and consequently follow a market- and competition-oriented approach in their higher education governance model, higher education institutions have become more like private sector firms in their governance and organization structures. In these countries, governments believe in the positive impact of competition; more direct relationships between the higher education institutions and their users or clients; private, diversified funding (including high levels of tuition fees); and economy-driven research agendas, implying a strong focus on the Life Sciences and STEM (Science, Technology, Engineering and Mathematics) disciplines. Here, the role of the state and the size and formal mandates of the public domain have been adapted and in many ways reduced over the last decades, and the political economy can be characterised as a liberal market economy (Hall and Soskice 2001).

Second, in those countries in which higher education is first and foremost regarded as one of the key instruments for implementing and realizing national political agendas, the higher education institutions' governance structures and practices are in general quite strictly controlled by the public authorities. This can be direct by selecting and appointing institutional academic and administrative leaders, or indirect through legal frameworks and policies that limit the institutional autonomy and through earmarked funding practices. Many policy initiatives are introduced to stimulate the higher education institutions' academic quality and socio-economic relevance, but often on a trial and error basis. This implies that there is a rather low level of stability in the institutions' environment, and they have to adapt regularly to new productivityenhancing policies and targets introduced by the public authorities. The political economy in these countries can be characterised as a state-led market economy (Hall and Soskice 2001).

Third, in those countries where the public authorities use a more balanced mixture of ideas underlying their higher education governance model overemphasizing one dominant vision, public funding levels remain relatively high, tuition fees are moderate, low or disallowed, and institutional governance models try to maintain 
a balance between democratic and executive principles and components. While we also see in these countries a growing reliance on the working of the market place and competition, and a focus on the contribution of higher education to innovation in the private sector, at the same time also the promotion of open societies, democracy and intercultural competences are important elements of the higher education governance approach. In these countries, the role of the state and the size and formal mandates of the public domain have been adapted but not necessarily reduced over the last decades, and the political economy can be characterised as a coordinated market economy (Hall and Soskice 2001).

\section{Development of Political Interest in the EHEA}

While political variety among countries participating in the EHEA has increased, the convergence of structural elements of the higher education systems in the EHEA, such as the introduction of ECTS, the three-cycle degree structure or quality assurance mechanisms, has successfully progressed since 1999 (Scott 2012). When looking at the stocktaking reports that have been prepared for the ministerial conferences, ${ }^{9}$ it becomes clear that structural differences are being reduced and higher education systems are converging towards a so-called "Bologna model". At the same time, national higher education governance models discussed above act as a filter for the implementation and interpretation of policies coming from the EHEA especially in cases where these policies conflict with interests or values on the national level (Gornitzka and Maassen 2014). Consequently, the diversity within the EHEA with respect to fundamental values and principles, such as institutional autonomy, academic freedom, and the social dimension of higher education (Yagci 2014) remains significant or has even increased in some aspects. Apparently, the science diplomacy approach described by Moedas (2016) has not had the effect of the EHEA becoming more homogeneous in the way the participating countries adhere to fundamental values in practice.

In parallel, the EHEA seems to become politically less salient over time. Earlier studies have shown that the level of political representation of full member delegations (excluding the European Commission) to the Ministerial Conferences of the EHEA has steadily declined between 1999 and 2015 with an especially steep decrease for EU member countries (Vukasovic et al. 2017). Following up on this study, we analysed the attendance lists of all Bologna Ministerial Conferences from 1999 to and including 2018. In this, we coded the level of political representation, that is, the title of the head of delegation, of each full member delegation (excluding the European Commission) on a 5-point scale, with 1 being the highest level of

\footnotetext{
${ }^{9}$ See: http://www.ehea.info/pid34367/implementation-and-national-reports.html, accessed 10 February 2020.
} 
Table 1 Mean level of political representation of the head of full member delegations

\begin{tabular}{l|l}
\hline Year & Mean level of political representation \\
\hline 1999 & 1.13 \\
\hline 2001 & 1.76 \\
\hline 2003 & 1.40 \\
\hline 2005 & 1.49 \\
\hline 2007 & 1.57 \\
\hline 2009 & 1.81 \\
\hline 2010 & 1.96 \\
\hline 2012 & 2.29 \\
\hline 2018 & 2.67 \\
\hline
\end{tabular}

representation (minister) and 5 the lowest (bureaucrats below the level of a Director General). ${ }^{10}$

When assessing the level of political representation of the full member delegations throughout the years, our results are in line with prior studies. Except for the last Ministerial Conference in Paris (Bologna Process 2018), we find a clear decrease in the mean level of political representation over time, dropping from a situation where most delegations were headed by ministers in 1999, to one where in 2015 most full member delegations were led by state secretaries or lower-level bureaucrats. In a way, this development lets one question whether the label "Bologna Ministerial Conference" is still appropriate given that in 2015, only 14 out of 46 full member delegations were headed by a minister. In 2018, the situation got somewhat better with 29 out of 49 full member delegations being headed by a minister. Overall, this suggests that the political salience of the EHEA is decreasing over time, as full members do not see it necessary anymore to be represented on the highest political level at the Ministerial Conferences. The data presented in Table 1 illustrate this overall trend, and even with the increase in the mean level of political representation in 2018, representation did not reach a level equal or higher than in the years up to 2009.

For analysing the mean level of political representation of the head of full member delegations, we have grouped the Bologna Ministerial Conference delegations in four groups:

\footnotetext{
${ }^{10}$ For a discussion on the problems of classifying the level of representation, see: Bergan and Deca (2018).
} 
Table 2 Mean level of political representation of the head of full member delegations grouped by EU membership status

\begin{tabular}{l|l|l|l|l}
\hline Year & EU member & EEA/EFTA & EU candidate & Neither \\
\hline 1999 & 1.00 & 2.00 & 1.00 & - \\
\hline 2001 & 1.63 & 1.75 & 1.77 & 2.25 \\
\hline 2003 & 1.31 & 2.25 & 1.15 & 1.50 \\
\hline 2005 & 1.42 & 1.75 & 1.25 & 1.62 \\
\hline 2007 & 1.57 & 2.75 & 1.00 & 1.33 \\
\hline 2010 & 1.76 & 3.00 & 1.67 & 1.58 \\
\hline 2012 & 2.00 & 1.50 & 3.00 & 1.77 \\
\hline 2015 & 2.45 & 3.33 & 2.00 & 1.75 \\
\hline & 3.04 & 2.75 & 2.40 & 1.67 \\
\hline
\end{tabular}

1. delegations that represented EU member countries at the time of the conference;

2. delegations that represented EEA or EFTA members at the time of the conference;

3. delegations that represented countries that were candidates for EU membership at the time of the conference;

4. delegations that did not fall in either of these categories.

Looking at the results presented in Table2, one can see that especially the level of political representation of delegations from EU member countries decreased over the years. Moreover, it is the increase in the level of representation of EU member countries for the 2018 Paris conference that drives the increase in the mean level of representation observed above. In general, one can observe that since 2007, delegations from countries that are not members of the EU or EFTA/EEA, nor a candidate to the EU, had on average a higher level of political representation than EU members. This suggests, in line with previous studies (Vukasovic et al. 2017), that the EHEA has more political salience for countries that are not part of the EU or EFTA/EEA.

\section{Adherence to Academic Freedom in the EHEA}

While most action lines in the EHEA are rather politically neutral, the 2015 Yerevan Communiqué emphasized the importance of shared values in the Bologna Process, referring explicitly to academic freedom and institutional autonomy. ${ }^{11}$ These values were already part of the initial 1999 Bologna Declaration with its reference to the Magna Charta Universitatum. ${ }^{12}$ While the Bologna Implementation Reports usu-

\footnotetext{
${ }^{11}$ See:http://www.ehea.info/media.ehea.info/file/2015_Yerevan/70/7/YerevanCommuniqueFinal_ 613707.pdf, accessed 10 February 2020.

${ }^{12}$ See: http://www.magna-charta.org/, accessed 10 February 2020.
} 
ally offer a wide set of data to assess the level of implementation of the different Action Lines in the member countries, the Bologna Implementation Report 2018 only presents a limited, relatively ineffective set of indicators to assess the state of the art as regards fundamental values in the EHEA (EU 2018). With regard to academic freedom, the report relies mainly on discussing problematic individual incidents in Turkey, Russia and Hungary, claiming that while concerns have been raised about violations of values in some EHEA countries, it would be difficult to find causal explanations. The report further points out that all but four higher education systems in the EHEA reported that academic freedom is mentioned in their national legislation with a varying degree of specification. The four systems that do not refer to academic freedom in their legislation are the Flemish Community in Belgium, Malta, Hungary and Belarus (EU 2018: 42).

To further investigate the values underpinning the EHEA, we used data from the Varieties of Democracy (V-Dem) dataset (version 9), which is prepared by the Department of Political Science at the University of Gothenburg (Coppedge et al. 2019, Pemstein et al. 2019). This dataset is widely used in political science research and it provides a number of indicators measuring different aspects of democracy. The data are generated using more than 3000 country experts that code countries on a number of variables. One of the variables measures the freedom of academic and cultural expression (3.8.1 v2clacfree) on a scale from zero (severe restrictions) to four (no restrictions). The variable includes yearly data for most countries in the world from 1789 until 2018. The only EHEA full members that are not included in the dataset and thus had to be excluded from our analysis are Andorra, the Holy See, and Liechtenstein. Based on the countries represented as full members at the Ministerial conferences, we used the V-Dem data to calculate the mean academic freedom value for each conference (see Table 3). The data show that the mean level of academic freedom decreases throughout the development of the EHEA, reaching

Table 3 Mean academic freedom level in Bologna member countries at each Ministerial Conference

\begin{tabular}{l|l|l}
\hline Year & $\begin{array}{l}\text { Number of } \\
\text { delegations }\end{array}$ & $\begin{array}{l}\text { Mean value of } \\
\text { academic freedom }\end{array}$ \\
\hline 1999 & 30 & 3.83 \\
\hline 2001 & 34 & 3.74 \\
\hline 2003 & 41 & 3.61 \\
\hline 2005 & 44 & 3.57 \\
\hline 2007 & 44 & 3.50 \\
\hline 2009 & 45 & 3.56 \\
\hline 2010 & 47 & 3.53 \\
\hline 2012 & 46 & 3.46 \\
\hline 2015 & 43 & 3.37 \\
\hline Total & 46 & 3.17 \\
\hline
\end{tabular}


Table 4 The level of academic freedom of each delegation's country by EU status at the time of the Ministerial Conference over the period 1999 until 2018

\begin{tabular}{l|l|l|l|l|l}
\hline & $\begin{array}{l}\text { Severely } \\
\text { restricted }\end{array}$ & Restricted & $\begin{array}{l}\text { Somewhat } \\
\text { restricted }\end{array}$ & $\begin{array}{l}\text { Few } \\
\text { restrictions }\end{array}$ & No restrictions \\
\hline $\begin{array}{l}\text { Neither } \\
\text { member nor } \\
\text { candidate to }\end{array}$ & 0 & 10 & 22 & 46 & 1 \\
$\begin{array}{l}\text { EU or } \\
\text { EFTA/EEA }\end{array}$ & & & & & \\
\hline EU candidate & 1 & 1 & 8 & 28 & 27 \\
\hline EFTA/EEA & 0 & 0 & 0 & 0 & 29 \\
\hline EU member & 0 & 0 & 2 & 28 & 221 \\
\hline
\end{tabular}

its lowest point in 2018. Using the mean value to describe the level of academic freedom throughout the EHEA, one could say that we moved from a situation where there were barely any restrictions on academic freedom to one where there are few restrictions. While this does not seem like a dramatic shift, the declining tendency in itself is worrying.

Moreover, when disaggregating the level of academic freedom following the above-mentioned groupings according to EU membership status, it becomes clear that especially delegations from countries that are neither members of nor candidates to the EU or EFTA/EEA have more limitations regarding their academic freedom. In Table 4 , an overview is presented of all 420 delegations that have attended Ministerial conferences over the years, clustered by the countries' EU membership status and the level of academic freedom according to the V-Dem data.

A 2-tailed correlation between an ordinal variable measuring the EU membership status of a country and its level of academic freedom shows that there is a significant and positive relation between a closer integration into the $\mathrm{EU}$ and less restrictions for academic freedom (Spearman's rho .691**, significant at .01 level). This is not entirely surprising given the general importance of EU citizens' rights in the process of EU accession, but the strength of the correlation points towards somewhat of a bifurcation in the full members of the EHEA with regard to the support for academic freedom. Table 5 presents the results of the two previous tables together and presents a detailed overview of the level of academic freedom by EU membership status for each individual Ministerial Conference. This table shows both the general decrease of the level of academic freedom over time in all EU membership categories except for the EEA/EFTA countries, and the bifurcation between EU and EFTA/EEA members on the one hand, and EU candidates and non-affiliated countries on the other. The latter are having, generally speaking, lower scores in their level of academic freedom.

The number of delegations from those countries that received the lowest scores for their level of academic freedom (restricted or severely restricted), actually increases over time reaching its peak in 2018 (see Table 6). Given that only one country joined the EHEA in 2015, this is a strong indicator of an erosion of the value-basis on 
Table 5 The level of academic freedom of each delegation's country by EU status for each Ministerial Conference

\begin{tabular}{|c|c|c|c|c|c|c|}
\hline Year & EU membership status & $\begin{array}{l}\text { Severely } \\
\text { restricted }\end{array}$ & Restricted & $\begin{array}{l}\text { Somewhat } \\
\text { restricted }\end{array}$ & $\begin{array}{l}\text { Few } \\
\text { restric- } \\
\text { tions }\end{array}$ & $\begin{array}{l}\text { No } \\
\text { restric- } \\
\text { tions }\end{array}$ \\
\hline \multirow[t]{4}{*}{1999} & $\begin{array}{l}\text { Neither member nor } \\
\text { candidate to EU or } \\
\text { EFTA/EEA }\end{array}$ & 0 & 0 & 0 & 0 & 0 \\
\hline & EU candidate & 0 & 0 & 0 & 4 & 8 \\
\hline & EFTA/EEA & 0 & 0 & 0 & 0 & 3 \\
\hline & EU member & 0 & 0 & 0 & 1 & 14 \\
\hline \multirow[t]{4}{*}{2001} & $\begin{array}{l}\text { Neither member nor } \\
\text { candidate to EU or } \\
\text { EFTA/EEA }\end{array}$ & 0 & 0 & 1 & 1 & 0 \\
\hline & EU candidate & 0 & 0 & 1 & 4 & 8 \\
\hline & EFTA/EEA & 0 & 0 & 0 & 0 & 3 \\
\hline & EU member & 0 & 0 & 0 & 0 & 16 \\
\hline \multirow[t]{4}{*}{2003} & $\begin{array}{l}\text { Neither member nor } \\
\text { candidate to EU or } \\
\text { EFTA/EEA }\end{array}$ & 0 & 1 & 1 & 7 & 0 \\
\hline & EU candidate & 0 & 0 & 0 & 4 & 9 \\
\hline & EFTA/EEA & 0 & 0 & 0 & 0 & 3 \\
\hline & EU member & 0 & 0 & 0 & 0 & 16 \\
\hline \multirow[t]{4}{*}{2005} & $\begin{array}{l}\text { Neither member nor } \\
\text { candidate to EU or } \\
\text { EFTA/EEA }\end{array}$ & 0 & 1 & 2 & 8 & 0 \\
\hline & EU candidate & 0 & 0 & 0 & 3 & 1 \\
\hline & EFTA/EEA & 0 & 0 & 0 & 0 & 3 \\
\hline & EU member & 0 & 0 & 0 & 1 & 25 \\
\hline \multirow[t]{4}{*}{2007} & $\begin{array}{l}\text { Neither member nor } \\
\text { candidate to EU or } \\
\text { EFTA/EEA }\end{array}$ & 0 & 1 & 4 & 5 & 0 \\
\hline & EU candidate & 0 & 0 & 0 & 3 & 0 \\
\hline & EFTA/EEA & 0 & 0 & 0 & 0 & 3 \\
\hline & EU member & 0 & 0 & 0 & 3 & 25 \\
\hline \multirow[t]{4}{*}{2009} & $\begin{array}{l}\text { Neither member nor } \\
\text { candidate to EU or } \\
\text { EFTA/EEA }\end{array}$ & 0 & 1 & 3 & 6 & 0 \\
\hline & EU candidate & 0 & 0 & 0 & 3 & 0 \\
\hline & EFTA/EEA & 0 & 0 & 0 & 0 & 3 \\
\hline & EU member & 0 & 0 & 0 & 2 & 27 \\
\hline \multirow[t]{4}{*}{2010} & $\begin{array}{l}\text { Neither member nor } \\
\text { candidate to EU or } \\
\text { EFTA/EEA }\end{array}$ & 0 & 1 & 3 & 6 & 1 \\
\hline & EU candidate & 0 & 0 & 1 & 2 & 0 \\
\hline & EFTA/EEA & 0 & 0 & 0 & 0 & 3 \\
\hline & EU member & 0 & 0 & 0 & 3 & 27 \\
\hline
\end{tabular}


Table 5 (continued)

\begin{tabular}{|c|c|c|c|c|c|c|}
\hline Year & EU membership status & $\begin{array}{l}\text { Severely } \\
\text { restricted }\end{array}$ & Restricted & $\begin{array}{l}\text { Somewhat } \\
\text { restricted }\end{array}$ & $\begin{array}{l}\text { Few } \\
\text { restric- } \\
\text { tions }\end{array}$ & $\begin{array}{l}\text { No } \\
\text { restric- } \\
\text { tions }\end{array}$ \\
\hline \multirow[t]{4}{*}{2012} & $\begin{array}{l}\text { Neither member nor } \\
\text { candidate to EU or } \\
\text { EFTA/EEA }\end{array}$ & 0 & 1 & 3 & 6 & 0 \\
\hline & EU candidate & 0 & 0 & 2 & 2 & 1 \\
\hline & EFTA/EEA & 0 & 0 & 0 & 0 & 2 \\
\hline & EU member & 0 & 0 & 0 & 4 & 25 \\
\hline \multirow[t]{4}{*}{2015} & $\begin{array}{l}\text { Neither member nor } \\
\text { candidate to EU or } \\
\text { EFTA/EEA }\end{array}$ & 0 & 1 & 3 & 3 & 0 \\
\hline & EU candidate & 0 & 1 & 2 & 2 & 0 \\
\hline & EFTA/EEA & 0 & 0 & 0 & 0 & 3 \\
\hline & EU member & 0 & 0 & 0 & 6 & 22 \\
\hline \multirow[t]{4}{*}{2018} & $\begin{array}{l}\text { Neither member nor } \\
\text { candidate to EU or } \\
\text { EFTA/EEA }\end{array}$ & 0 & 3 & 2 & 4 & 0 \\
\hline & EU candidate & 1 & 0 & 2 & 1 & 0 \\
\hline & EFTA/EEA & 0 & 0 & 0 & 0 & 3 \\
\hline & EU member & 0 & 0 & 2 & 8 & 20 \\
\hline
\end{tabular}

Table 6 Delegations from countries with restricted or severely restricted academic freedom over time

\begin{tabular}{l|l}
\hline Year & Delegations \\
\hline 1999 & 0 \\
\hline 2001 & 0 \\
\hline 2003 & 1 \\
\hline 2005 & 1 \\
\hline 2007 & 1 \\
\hline 2009 & 1 \\
\hline 2010 & 1 \\
\hline 2012 & 1 \\
\hline 2015 & 2 \\
\hline 2018 & 4 \\
\hline
\end{tabular}

which the EHEA is supposed to be built. Moreover, the fact that the number of delegations from countries with serious academic freedom challenges is the highest at the Ministerial Conference following the Yerevan Communiqué with its focus on highlighting the EHEA's fundamental values puts the ability of the EHEA to safeguard and promote the values, on which it claims to be built, into question.

In Table 7, an overview is presented of the total number of full delegations of all EHEA countries that participated in the Ministerial Conferences from countries 
Table 7 Number of delegations to Ministerial Conferences from countries with restricted or severely restricted levels of academic freedom at the time of the conference

\begin{tabular}{l|l}
\hline Country & $\begin{array}{l}\text { Delegations between 1999 } \\
\text { and 2018 }\end{array}$ \\
\hline Azerbaijan & 6 \\
\hline Belarus & 3 \\
\hline Russia & 1 \\
\hline Turkey & 2 \\
\hline
\end{tabular}

having the lowest scores for their academic freedom (restricted or severely restricted) in the respective years of the conference. In this, we only count delegations to conferences in years when the country had one of the lowest scores with respect to its academic freedom. The results show that four countries have sent delegations to Ministerial Conferences while having problematic academic freedom scores. The optimistic interpretation of Table 7 is that only four countries have or had severe problems with their academic freedom. In a more pessimistic interpretation, one could argue that both Russia and Turkey are long time EHEA members that experienced a backsliding in their academic freedom scores in recent years despite their participation in the EHEA. Moreover, Azerbaijan shows a steady level of restricted academic freedom scores throughout its membership in the EHEA since 2005. Finally, Belarus, the most recent member of the EHEA, was able to join despite its problematic academic freedom situation. While Belarus was admitted only after agreeing to a roadmap which also included enhancing academic freedom, the results of the analysis raise doubts about the implementation of this roadmap as well as about how important the values and principles that are claimed to be at the foundation of the EHEA are in practice.

The 2018 Bologna Implementation Report (European Commission/EACEA/ Eurydice [EU] 2018) highlighted that nearly all EHEA countries have academic freedom in some way enshrined in their laws. When it comes to the four countries included in Table 7, only Belarus does not mention academic freedom in its law. This strongly suggests that the indicator used by the Bologna Implementation Report is not sufficiently insightful for assessing the level of academic freedom in the EHEA countries.

Consequently, from a science diplomacy perspective, it can be argued that the EHEA represents a form of collaboration, which aims at staking out a path of common interests for all countries involved instead of being an arena for resolving possible and real political disagreements and conflicts. The common interests highlighted concern mainly academic and economic aspects, while fundamental values and principles are playing a merely symbolic role. It can be assumed that serious efforts to include values and principles in the core agenda and commitments of the EHEA and monitor how each country 'honours and promotes' them would make it necessary to address far-reaching political differences among the EHEA countries. Therefore, trying to enforce the promotion of the identified fundamental values and principles in all EHEA countries would very likely threaten the continued existence of the EHEA in its current form. 


\section{EU and Beyond-Multiple Patterns of Coordination and the Future of EHEA}

One question emerging from the above analyses is how the variations in political ideologies, geographical scope, and economic strength affect inter-country collaboration until now, and ultimately also the next phase of the EHEA. In this, we will focus especially on EU funded collaboration.

The EU has historically been constrained in developing a coherent higher education policy (Corbett 2005), and the Bologna Process was initiated outside of the EU framework as an intergovernmental process. Nonetheless, the EU quickly became involved with the Bologna Process, especially by providing EU funding (Gornitzka 2009). While formal EU political coordination in higher education is legally constrained, the EU has funding capacity. This allows for various types of educational programmes across Europe, such as ERASMUS+, and capacity building programmes beyond Europe in education. In the implementation of these, specific programme features and aims meet overall EHEA policy aims, including fundamental values and principles, without the latter being accepted as framework conditions for programmespecific funding decisions. Budgets for higher education collaboration have been expanding. ERASMUS+ funding for the period 2014-2020 was $€ 14.7$ billion, an increase from the $€ 7$ available for its predecessor, the Lifelong Learning Programme (2007-2013). ${ }^{13}$ In March $2019^{14}$ it was announced that the proposed budget for the next period (2021-2027) would be tripled, after initial indications of doubling the budget. $^{15}$

The different programmes allow for various kinds of emphases when it comes to collaboration, competition and consequently, prestige. While the EHEA-EU relationship is presented as frictionless, EU programmes aimed at higher education offer some EHEA countries a comparatively strong platform for cooperation. This means that EHEA countries that are, for example, geographically further away, and, as discussed above, in some instances also have restricted or severely restricted academic freedom track records, are involved much more marginally in EU programme funded education projects. The exception to this is formed by the EU capacity building programmes.

\footnotetext{
${ }^{13}$ Overview of ERASMUS+ Predecessor programmes, https://ec.europa.eu/research/fp7/pdf/fp7factsheets_en.pdf, accessed 10 February 2020.

${ }^{14}$ Press release from the European Parliament, 28 March 2019 https://www.europarl.europa. eu/news/en/press-room/20190321IPR32121/erasmus-2021-2027-more-people-to-experiencelearning-exchanges-in-europe, accessed 10 February 2020.

${ }^{15}$ Press release on EU budget, 30 May 2018, https://ec.europa.eu/commission/presscorner/detail/ en/IP_18_3948, accessed 10 February 2020.
} 


\subsection{EU Funding for Collaboration-Strategic Partnerships in Higher Education}

In the area of education, the main EU funding instruments are included in the Erasmus+ programme, which has three Key Action (KA) areas: individual mobility (KA1); cooperation for innovation and exchange of good practices (KA2); and support for policy reform (KA3). ${ }^{16}$ More recently, KA2 project funding also includes the European Universities Initiative. ${ }^{17}$

This section presents KA2 project funding patterns in the area of higher education. Our main interest concerns the rate of participation of higher education institutions from each individual country, as project coordinator and participant in KA2 projects. ${ }^{18}$ First, in Table 8 an overview is presented of the total number of Strategic Partnerships for Higher Education projects coordinated per country. The data set includes 1227 projects from the period 2014-2019. The overall number of projects has been growing substantially during the whole ERASMUS+ period-from 121 in 2014 to 329 in 2019. In terms of funding, these projects are specified and sometimes rather limited in scope, ranging from about $€ 40000$ to about $€ 450000$.

In this overview, we have not looked into the number of partner institutions in each country, only country participation over time in project consortia. ${ }^{19}$ This means that a single institution can participate in several consortia at the same time, while there can be several institutions from the same country in a single consortium. Our interest lies in the broad participation patterns and country patterns. Here, the picture that emerges is relatively widely spread across Europe. In 2019, the countries that coordinated most projects were Spain, Germany, France, Poland and the United Kingdom. Aggregating the numbers to the four main geographical groups as determined in the calls (north, south, east, west), the picture is stable over time (see Table 9). Institutions from Central and Eastern Europe coordinate between 20 and $26 \%$ of the projects (in 2019, $24 \%$ ), around $15 \%$ of projects are coordinated by an institution from a Northern European country, between 24 and 28\% from Southern Europe and around 35\% from Western Europe.

Looking into project partner countries in consortia, a somewhat different picture emerges (see Table 10). Funded consortia most often include partner institution(s) from Spain, Italy and Germany. This could also be explained by the fact that other Southern European countries are smaller which then leads to higher concentration of projects in institutions from Spain and Italy in projects where one is required to include a partner from Southern Europe. Here, also Germany (117) and the United Kingdom (86) are well represented as well as smaller countries, such as Belgium (74)

\footnotetext{
${ }^{16}$ See: https://ec.europa.eu/programmes/erasmus-plus/node_en, accessed 10 February 2020.

${ }^{17} \mathrm{See}$ : https://ec.europa.eu/education/education-in-the-eu/european-education-area/european-uni versities-initiativel_en, accessed 10 February 2020

${ }^{18}$ This means that higher education institutions that are project coordinators are in Table 10 also counted as members of the consortia.

${ }^{19}$ Optimally, both should be done, but for the purposes of this analysis, we aim to identify which countries and regions are well represented in the funding schemes.
} 
Table 8 KA2 - Strategic partnerships for higher education: number of projects per country (coordinator institution)

\begin{tabular}{|c|c|c|c|c|c|c|}
\hline Country & 2014 & 2015 & 2016 & 2017 & 2018 & 2019 \\
\hline Spain & 12 & 15 & 15 & 16 & 20 & 30 \\
\hline Germany & 10 & 14 & 14 & 17 & 21 & 27 \\
\hline France & 8 & 10 & 9 & 12 & 17 & 26 \\
\hline Poland & 10 & 12 & 9 & 14 & 20 & 26 \\
\hline United Kingdom & 9 & 8 & 16 & 19 & 22 & 26 \\
\hline Italy & 4 & 8 & 8 & 12 & 16 & 19 \\
\hline Turkey* & 7 & 9 & 12 & 14 & 9 & 16 \\
\hline Romania & 7 & 6 & 7 & 7 & 7 & 14 \\
\hline Belgium & 2 & 9 & 2 & 4 & 7 & 13 \\
\hline Netherlands & 6 & 7 & 7 & 8 & 10 & 12 \\
\hline Czech & 4 & 4 & 4 & 4 & 7 & 11 \\
\hline Denmark & 1 & 2 & 3 & 6 & 7 & 11 \\
\hline Sweden & 4 & 5 & 5 & 6 & 11 & 10 \\
\hline Finland & 1 & 3 & 2 & 2 & 4 & 7 \\
\hline Greece & 3 & 3 & 4 & 5 & 7 & 7 \\
\hline Norway* & 3 & 6 & 4 & 5 & 5 & 7 \\
\hline Portugal & 2 & 3 & 2 & 6 & 6 & 7 \\
\hline Austria & 4 & 3 & 3 & 3 & 5 & 6 \\
\hline Croatia & 1 & 2 & 2 & 2 & 3 & 6 \\
\hline Hungary & 2 & 3 & 3 & 3 & 6 & 6 \\
\hline Bulgaria & 1 & 1 & 2 & 3 & 5 & 5 \\
\hline Lithuania & 2 & 3 & 3 & 3 & 3 & 5 \\
\hline Estonia & 1 & 2 & 3 & 6 & 7 & 4 \\
\hline Iceland* & 3 & 3 & 3 & 1 & 3 & 4 \\
\hline Slovakia & 3 & 2 & 2 & 3 & 5 & 4 \\
\hline Slovenia & 3 & 2 & 2 & 2 & 2 & 4 \\
\hline Cyprus & 1 & 2 & 2 & 2 & 2 & 3 \\
\hline Ireland & 1 & 2 & 1 & 2 & 2 & 3 \\
\hline Liechtenstein* & 2 & 2 & 3 & 3 & 4 & 3 \\
\hline Latvia & 1 & 3 & 2 & 3 & 3 & 2 \\
\hline Malta & 0 & 2 & 3 & 2 & 2 & 2 \\
\hline Serbia* & 0 & 0 & 0 & 0 & 2 & 2 \\
\hline Luxembourg & 2 & 2 & 2 & 3 & 1 & 1 \\
\hline Rep of North Macedonia* & 1 & 2 & 3 & 3 & 3 & 0 \\
\hline Total number of projects & 121 & 160 & 162 & 201 & 254 & 329 \\
\hline
\end{tabular}

*Non-EU members 
Table 9 KA2 - Strategic partnerships for higher education: project coordinating institution, \% region (Refers to north, south, east, west categorization used in Erasmus+ funding calls, set by EuroVoc.) of origin (2014-2019)

\begin{tabular}{l|l|l|l|l|l|l}
\hline & $2014(\%)$ & $2015(\%)$ & $2016(\%)$ & $2017(\%)$ & $2018(\%)$ & $2019(\%)$ \\
\hline East & 26 & 21 & 21 & 20 & 24 & 24 \\
\hline North & 13 & 17 & 15 & 16 & 17 & 15 \\
\hline South & 24 & 26 & 28 & 28 & 24 & 26 \\
\hline West & 36 & 36 & 35 & 35 & 35 & 36 \\
\hline
\end{tabular}

Table 10 KA2-Strategic partnerships for higher education: number of times a consortium includes an institution from this country

\begin{tabular}{l|c|c|c|c|c|c}
\hline Country & 2014 & 2015 & 2016 & 2017 & 2018 & 2019 \\
\hline Spain & 52 & 67 & 58 & 70 & 111 & 145 \\
\hline Italy & 44 & 59 & 63 & 74 & 95 & 139 \\
\hline Germany & 40 & 52 & 53 & 71 & 87 & 117 \\
\hline United Kingdom & 51 & 47 & 62 & 61 & 67 & 86 \\
\hline Belgium & 29 & 50 & 38 & 53 & 51 & 74 \\
\hline Portugal & 24 & 40 & 33 & 49 & 64 & 74 \\
\hline Poland & 32 & 33 & 31 & 42 & 67 & 72 \\
\hline Netherlands & 31 & 39 & 39 & 48 & 52 & 70 \\
\hline France & 32 & 32 & 27 & 42 & 54 & 67 \\
\hline Greece & 19 & 28 & 25 & 36 & 44 & 62 \\
\hline Finland & 21 & 22 & 30 & 32 & 51 & 47 \\
\hline Romania & 18 & 30 & 27 & 33 & 36 & 47 \\
\hline Austria & 19 & 24 & 20 & 26 & 36 & 45 \\
\hline Sweden & 17 & 21 & 22 & 21 & 34 & 43 \\
\hline Lithuania & 18 & 15 & 21 & 25 & 25 & 41 \\
\hline Hungary & 11 & 19 & 19 & 18 & 29 & 40 \\
\hline Turkey* & 15 & 12 & 20 & 19 & 18 & 38 \\
\hline Czech & 19 & 17 & 20 & 22 & 37 & 35 \\
\hline Denmark & 13 & 13 & 15 & 18 & 33 & 35 \\
\hline Norway* & 13 & 14 & 16 & 21 & 21 & 31 \\
\hline Slovenia & 18 & 11 & 24 & 19 & 29 & 31 \\
\hline Ireland & 15 & 13 & 13 & 22 & 23 & 30 \\
\hline Cyprus & 4 & 7 & 9 & 5 & 17 & 28 \\
\hline Bulgaria & 6 & 11 & 10 & 19 & 16 & 25 \\
\hline Croatia & 2 & 6 & 14 & 16 & 19 & 23 \\
\hline Estonia & 9 & 13 & 14 & 17 & 22 & 23 \\
\hline Slovakia & 13 & 12 & 7 & 18 & 17 & 19 \\
\hline & & & & & & $($ continued) \\
\hline & & & & & & \\
\hline
\end{tabular}


Table 10 (continued)

\begin{tabular}{l|c|c|c|c|c|c}
\hline Country & 2014 & 2015 & 2016 & 2017 & 2018 & 2019 \\
\hline Iceland* & 6 & 4 & 6 & 3 & 10 & 15 \\
\hline Latvia & 6 & 7 & 11 & 11 & 13 & 15 \\
\hline Malta & 3 & 8 & 9 & 9 & 5 & 15 \\
\hline Serbia* & 2 & 1 & 2 & 1 & 3 & 15 \\
\hline Luxembourg & 5 & 4 & 4 & 10 & 13 & 11 \\
\hline Rep of North Macedonia* & 2 & 4 & 4 & 6 & 9 & 5 \\
\hline Liechtenstein* & 3 & 2 & 3 & 3 & 4 & 3 \\
\hline Total number of projects & $\mathbf{1 2 1}$ & $\mathbf{1 6 0}$ & $\mathbf{1 6 2}$ & $\mathbf{2 0 1}$ & $\mathbf{2 5 4}$ & $\mathbf{3 2 9}$ \\
\hline
\end{tabular}

*Non-EU members

and Portugal (74). Countries with low participation rates (under 20) are generally also smaller countries (Slovak Republic, Latvia, Malta, Luxembourg), and several of the non-European Erasmus+ countries can be found there (Iceland, Serbia, North Macedonia, Liechtenstein).

\subsection{European Universities Initiative}

The European Universities Initiative (EUI) represents in many ways the ideas that have been circulating in some segments of European higher education, emphasizing the role universities and colleges should play in the construction of the European project. The initiative has been flagged as an important dimension in the further development of the EHEA. The suggestion of a stronger, more integrated form of collaboration between higher education institutions in Europe was introduced in President Macron's September 2017 speech at the Sorbonne. ${ }^{20}$ In the same year, the Commission proposed the EUI at the Gothenburg Social Summit, and in December 2017 the European Council endorsed it, calling for:
"strengthening strategic partnerships across the EU between higher education institutions and encouraging the emergence by 2024 of some twenty 'European Universities', consisting in bottom-up networks of universities across the EU which will enable students to obtain a degree by combining studies in several EU countries and contribute to the international competitiveness of European universities" (European Council 2017)

A central idea in the first pilot Call of the EUI was that all alliances to be funded should promote European values and identity, in this manner also linking the Initiative to Article 2 in the EU Treaty. In addition, it was expected that the selected alliances would make "substantial leaps" in terms of "quality, performance, attractiveness and international competitiveness of European higher education institutions

\footnotetext{
${ }^{20}$ The transcript of the speech can be found at: https://www.diplomatie.gouv.fr/IMG/pdf/english_ version_transcript_-_initiative_for_europe_-_speech_by_the_president_of_the_french_republic_ cle8de628.pdf, accessed 10 February 2020.
} 
Table 11 European

Universities Initiative: number of coordinating institutions of first 17 EUI alliances, per country (2019)

\begin{tabular}{l|l}
\hline Country & \# Coordinating institutions \\
\hline France & 6 \\
\hline Germany & 3 \\
\hline Spain & 3 \\
\hline the Netherlands & 2 \\
\hline Belgium & 1 \\
\hline Hungary & 1 \\
\hline Slovenia & 1 \\
\hline Total & $\mathbf{1 7}$ \\
\hline
\end{tabular}

and contributing to the European knowledge economy, employment, culture and welfare by making best use of innovative pedagogies and striving to make the knowledge triangle" (Erasmus+ Programme Guide 2019). The involved higher education institutions commit themselves to organise $50 \%$ student mobility as a standard feature and to develop joint curricula.

To start with, two approaches to collaboration are being tested in two different calls (2019 and 2020). While initially the budget for the first Call was $€ 60$ million, due to the large number of high-quality applications, this was increased to $€ 85$ million with each selected alliance receiving $€ 5$ million in the next 3 years. In the second Call, with a deadline 26 February 2020, a different format was tested. Finally, in the upcoming 2021-2027 budget period, a significantly larger budget and a more established format is expected.

The results from the first Call show that of the 54 applications, 17 alliances were selected. They include in total 114 higher education institutions from 24 countries, yet the distribution of institutions per country is rather uneven. Rather unsurprisingly, large EU member states dominate the picture. However, even if it is required that the alliances cover different regions (North, South, East, West), 12 of the 17 consortia are led by a university in Western Europe, 2 by a university in Central and Eastern Europe, and 3 in Southern Europe, while none is led by a Northern European ${ }^{21}$ university (see Table 11).

While it can be argued that in a programme such as the EUI, the coordinator role is less important, there is also geographical unevenness in terms of overall alliance membership (see Table 12). The 16 French and 15 German institutions involved participate in 14 out of the 17 alliances, with one alliance having two French and two German universities as a partner. Overall, it is noteworthy that a substantial share of the participating institutions comes from Western European countries (46 of 114). Further, it is notable that there are only three universities from the United Kingdom included and no Turkish universities. While firm data on the development process of the 17 selected alliances are currently lacking, a possible assumption is that the institutions that have initiated these 17 alliances have, for political reasons,

\footnotetext{
${ }^{21}$ Note that the EU definition of Northern Europe here also includes the Baltic countries, which are sometimes grouped together with Central and Eastern Europe.
} 
Table 12 European Universities Initiative: number of participating higher education institutions per country in first 17 EUI alliances (2019)

\begin{tabular}{l|l}
\hline Country & \# Institutions in alliances \\
\hline France & 16 \\
\hline Germany & 15 \\
\hline Italy & 12 \\
\hline Spain & 11 \\
\hline Sweden & 6 \\
\hline Hungary & 5 \\
\hline Poland & 5 \\
\hline Belgium & 4 \\
\hline Finland & 4 \\
\hline Netherlands & 4 \\
\hline Greece & 3 \\
\hline Lithuania & 3 \\
\hline Portugal & 3 \\
\hline Romania & 3 \\
\hline United Kingdom & 3 \\
\hline Austria & 2 \\
\hline Croatia & 2 \\
\hline Czech & 2 \\
\hline Denmark & 2 \\
\hline Ireland & 2 \\
\hline Latvia & 2 \\
\hline Norway** & 2 \\
\hline Cyprus & 1 \\
\hline Malta & 1 \\
\hline Slovenia & 1 \\
\hline Bulgaria, Estonia, Iceland**, Liechtenstein**, Luxembourg, Rep of North Macedonia**, Ser- \\
bia**, Slovakia, and Turkey** had no participating higher education institutions \\
\hline Eligible countries which are not EU members & \\
\hline
\end{tabular}

avoided to invite Turkish universities. In addition, Brexit can be assumed to have had an impact on the below par representation of universities from the United Kingdom (compared, e.g., to the participation of UK institutions in Erasmus+ projects).

Yet, these data do not really give a good indication of the scope of the participating institutions in their country. Therefore, we have assessed the share of EUI participating institutions' student numbers in their respective countries' overall student population (see Table 13). It is rather striking that already through this first Call in 12 of the 24 involved countries at least one in five students will get an opportunity to study in a context where European collaboration between institutions is significantly strengthened. 
Table 13 Approximate share of students per country who are enrolled in higher education institutions that are part of one of the 17 first EUI alliances

\begin{tabular}{l|l}
\hline Country & Share of students $(\%)$ \\
\hline Malta & 79 \\
\hline SIovenia & 49 \\
\hline Sweden & 38 \\
\hline Greece & 27 \\
\hline Italy & 26 \\
\hline Finland & 26 \\
\hline Lithuania & 24 \\
\hline Hungary & 23 \\
\hline France & 23 \\
\hline Czech & 20 \\
\hline Belgium & 20 \\
\hline Spain & 19 \\
\hline Denmark & 16 \\
\hline Latvia & 16 \\
\hline Croatia & 15 \\
\hline Ireland & 14 \\
\hline Germany & 12 \\
\hline The Netherlands & 11 \\
\hline Poland & 11 \\
\hline Norway & 10 \\
\hline Romania & 8 \\
\hline Austria & 8 \\
\hline Cyprus & 8 \\
\hline United Kingdom & 3 \\
\hline Sources EURSTAT(2016, & SCED \\
\hline
\end{tabular}

Sources EUROSTAT (2016, number of students, ISCED 5-7), ETER database for institutional enrolments (ISCED 5-7, 2016/2017), overview of consortia membership. Note: Some of the institutions had missing values in the ETER database, which we have supplemented from numbers from institutional websites and alternative sources. Moreover, the shares are calculated per 2016 data, and in some countries, merger processes have taken place since. Therefore, the percentages should be seen as estimates.

\section{Conclusion}

The perspective on the recent developments in and future of the EHEA discussed in this paper implies complementing the focus on the structural and technical progress made in the EHEA with an appropriate inclusion of fundamental values and principles in intra-European higher education collaboration. The data presented in the paper on declining political interest in the EHEA throughout the 48 participating countries and the deterioration of the situation with respect to fundamental values, especially academic freedom, in a number of EHEA countries can be interpreted as 
an important challenge to the future of the EHEA. In addition, the overview of EU funded Erasmus+ (KA2) projects, and especially the first 17 alliances selected in the first EUI Call, shows that there are important variations between the four EHEA regions when it comes to the level of project leadership and participation.

The first Call of the EUI is of relevance for identifying an appropriate future trajectory for the EHEA. The introduction of the EUI can be regarded as a start of an ambitious new phase in intra-European higher education collaboration, moving from relatively short-term project collaboration to a more programmatic, long-term, integrated level of collaboration. The data of the outcomes of the first Call of the EUI show that especially higher education institutions in the four largest Continental European EU member states have been successful, while also Eastern European EU member states are well-represented. On the other hand, the very low UK participation and lack of Turkish institutions in the 17 first EUI alliances strongly suggest that political considerations have been taken into account in the composition of the alliances. From the perspective of the foreseen budget for the EUI and the large interest and commitment from the higher education institutions in the EU/EFTA countries to form EUI alliances, as well as the profiles of these alliances' joint programmes, the first Call of the EUI might indeed be the beginning of an important transformation in European higher education. To do justice to and further develop this transformation, it is necessary that the participating countries are more explicitly and effectively committed to fundamental values and principles than is currently the case in the EHEA, as shown in this paper.

The lack of action in the EHEA to stimulate that the agreed upon commitment to fundamental values and principles is followed up in practice hinders, amongst other things, the development of a clear European identity in higher education. As indicated by heads of state of major EU countries as well as the new EU Commission, the growing global political, economic and scientific rivalry, with especially the USA and China, demands a clear and strong European identity. The role of higher education in the promotion and development of this identity is crucial. But, as indicated, the EHEA is currently not the arena where European identity ambitions can be comprehensively and effectively boosted and realised.

What might the data presented and analysed in this paper imply for the future of the EHEA? Two complementary trajectories can be presented here, the first implying a move away from the geographical focus on Europe, the second a move back to a core of EU, EU membership candidate and EFTA countries. The first trajectory would imply moving from a European to a Global Higher Education Area. Such a move would imply connecting higher education systems and institutions around the world through a global programme incorporating EHEA components, such as student and staff mobility, mutual recognition of credit points, educational quality and the use of digital technologies. This could, amongst other things, contribute in a meaningful way to strengthening the contributions of higher education to the realisation of the SDGs. In practice, this could imply creating regional/continental Higher Education Areas that are based on the same structural and technical components as the EHEA, that is, converging degree structures, developing joint quality assessment procedures and structures, and reducing barriers for student and staff mobility, not only within 
each region but also between the regions. In this way, a Global Higher Education Area could be created, of which European Higher Education would make up one of the regional components.

The second trajectory would imply making the adherence to fundamental values and principles a central element in the creation and maintenance of a new common area for European universities and colleges. This new area will be more integrated and more anchored in a common European identity than the current EHEA. In this trajectory, the basic aims and components would include institutional integration instead of project collaboration. This trajectory would follow the path laid out by the ambitions and emerging practices of the European Universities Initiative and the higher education institutions participating in the selected alliances. Membership and participation in this new area would be dependent upon a set of framework conditions, including adherence to agreed upon fundamental values and principles. For such a new area to be effective and relevant, an independent monitoring body could be established, with a mandate to develop transparent and relevant indicators and to report regularly on the situation with respect to all framework conditions, including values and principles in all participating countries. If a country does not adhere to the agreed upon framework conditions, membership of the new area should be suspended. Putting fundamental values and principles at the core of the new area would potentially provide a foundation for science diplomacy negotiations with European countries that are not part of it. This could, for example, allow for an inclusion of these countries in the new area as associate members, as long as they adhere in practice to the framework conditions on which the new area is to be founded.

Obviously, the ultimate consequence of the two trajectories would be the disbandment of the EHEA in its current form.

\section{References}

Bergan, S., \& Deca, L. (2018). Twenty Years of Bologna and a Decade of EHEA: What Is Next? In A. Curaj, L. Deca, \& R. Pricopie (Eds.), European Higher Education Area: The Impact of Past and Future Policies (pp. 295-319). Cham: Springer.

Berkman, P.A. (2019). Evolution of Science Diplomacy and Its Local-Global Applications [Special issue] European Foreign Affairs Review, 24, 63-80.

Bologna Process (1999). The Bologna Declaration of 19 June 1999. Accessed 10 February 2020: http://www.ehea.info/media.ehea.info/file/Ministerial_conferences/02/8/1999_Bologna_ Declaration_English_553028.pdf

Bologna Process (2018). Paris Communiqué, 25-05-2018. Accessed 10 February 2020: http:// www.ehea.info/media.ehea.info/file/2018_Paris/77/1/EHEAParis2018_Communique_final_ 952771.pdf.

Coppedge, Michael, John Gerring, Carl Henrik Knutsen, Staffan I. Lindberg, Jan Teorell, David Altman, Michael Bernhard, M. Steven Fish, Adam Glynn, Allen Hicken, Anna Lührmann, Kyle L. Marquardt, Kelly McMann, Pamela Paxton, Daniel Pemstein, Brigitte Seim, Rachel Sigman, Svend-Erik Skaaning, Jeffrey Staton, Steven Wilson, Agnes Cornell, Lisa Gastaldi, Haakon Gjerløw, Nina Ilchenko, Joshua Krusell, Laura Maxwell, Valeriya Mechkova, Juraj Medzihorsky, Josefine Pernes, Johannes von Römer, Natalia Stepanova, Aksel Sundström, Eitan Tzelgov, Yi- 
ting Wang, Tore Wig, \& Daniel Ziblatt. (2019). V-Dem [Country-Year/Country-Date] Dataset v9, Varieties of Democracy (V-Dem) Project. https://doi.org/10.23696/vdemcy19

Corbett, A. (2005). Universities and the Europe of knowledge: ideas, institutions and policy entrepreneurship in European Union higher education policy, 1955-2005. Basingstoke: Palgrave Macmillan.

ENQA (2015). Standards and Guidelines for Quality Assurance in the European Higher Education Area (ESG). Brussels, Belgium. https://enqa.eu/wp-content/uploads/2015/11/ESG_2015. pdf, accessed 10 February 2020

European Commission/EACEA/Eurydice [EU]. (2018). The European Higher Education Area in 2018: Bologna Process Implementation Report. Luxembourg: Publications Office of the European Union available at https://eacea.ec.europa.eu/national-policies/eurydice/content/europeanhigher-education-area-2018-bologna-process-implementation-report_en, accessed 10 February 2020

European Commission. (2019). Erasmus+ Programme Guide. Brussels: European Commission. https://ec.europa.eu/programmes/erasmus-plus/resources/documents/erasmus-programmeguide-2020_en, accessed 10 February 2020

European Council. (2017). European Council meeting (14 December 2017) - Conclusions. EUCO 19/1/17 REV 1 In. Brussels, 14 December 2017.

Gornitzka, ̊. (2009). Networking Administration in Areas of National Sensitivity: The Commission and European Higher Education. In A. Amaral, G. Neave, C. Musselin, \& P. Maassen (Eds.), European Integration and the Governance of Higher Education and Research (Vol. 26, pp. 109131). Dordrecht: Springer.

Gornitzka, Å., \& Maassen, P. (2014). Dynamics of Convergence and Divergence. Exploring Accounts of Higher Education Policy Change. In P. Mattei (Ed.), University Adaptation in Diffcult Economic Times (pp. 13-29). Oxford: Oxford University Press.

Hall, P.A., \& Soskice, D. (2001). Varieties of capitalism: The institutional foundations of comparative advantage. Oxford: Oxford University Press.

Maassen P., \& Olsen, J.P. (Eds.) (2007). University dynamics and European integration. Dordrecht: Springer.

Moedas, C. (2016). Science diplomacy in the European Union. Science \& Diplomacy, 5(1), 1-9.

Olsen, J.P. (2007). The institutional dynamics of the European university. In P. Maassen and J. P. Olsen (Eds.), University dynamics and European integration (pp. 25-55). Dordrecht, the Netherlands: Springer.

Pemstein, Daniel, Kyle L. Marquardt, Eitan Tzelgov, Yi-ting Wang, Juraj Medzihorsky, Joshua Krusell, Farhad Miri, \& Johannes von Römer. (2019). The V-Dem Measurement Model: Latent Variable Analysis for Cross-National and Cross-Temporal Expert-Coded Data, V-Dem Working Paper No. 21. 4th edition. University of Gothenburg: Varieties of Democracy Institute.

Scott, P. (2012). Going Beyond Bologna: Issues and Themes. In A. Curaj, P. Scott, L. Vlasceanu, \& L. Wilson (Eds.), European Higher Education at the Crossroads: Between the Bologna Process and National Reforms (pp. 1-14). Dordrecht: Springer.

Vukasovic, M., Jungblut, J., \& Elken, M. (2017). Still the main show in town? Assessing political saliency of the Bologna Process across time and space. Studies in Higher Education, 42(8), 1421-1436. https://doi.org/10.1080/03075079.2015.1101755

Yagci, Y. (2014). Setting Policy Agenda for the Social Dimension of the Bologna Process. Higher Education Policy, 27(4), 509-528. doi:https://doi.org/10.1057/hep.2013.38 
Open Access This chapter is licensed under the terms of the Creative Commons Attribution 4.0 International License (http://creativecommons.org/licenses/by/4.0/), which permits use, sharing, adaptation, distribution and reproduction in any medium or format, as long as you give appropriate credit to the original author(s) and the source, provide a link to the Creative Commons license and indicate if changes were made.

The images or other third party material in this chapter are included in the chapter's Creative Commons license, unless indicated otherwise in a credit line to the material. If material is not included in the chapter's Creative Commons license and your intended use is not permitted by statutory regulation or exceeds the permitted use, you will need to obtain permission directly from the copyright holder. 